\title{
CORK FROM QUERCUS SUBER L.: FOREST CERTIFICATION SYSTEM FOR SUSTAINABLE MANAGEMENT OF CORK OAK FORESTS
}

\author{
Ignacio J. Diaz-Maroto \\ Universidad De Santiago De Compostela \\ SPAIN \\ María Consuelo Diaz-Maroto \\ Universidad De Castilla-La Mancha \\ Spain \\ (Received March 2020)
}

\begin{abstract}
Cork is the outer bark of the cork oak (Quercus suber L.), it is a secondary protection structure of tree, and its chemical composition is different from that of other lignocellulosic materials, as wood, agricultural, or forestry wastes. The best cork sheets are used to manufacture natural cork stoppers, vital in the aging process of "great" wines. It is a Mediterranean species covering an overall area of 2,139,942 hectares; Portugal and Spain countries where it occupies a larger area.

This paper was developed to assess the possibility of implementing a system of payment for ecosystem services and/or a certification of forest management for small stands of cork oak privately owned areas of less than 25 hectares. The process is leaded by the Regional Groups of Forest Certification and Chain of Custody, main regional institutions. The system used is the Programme for the Endorsement of Forest Certification (PEFC). As specified by the multifunctional forestry applied in these ecosystems, its main use is the production of natural cork stoppers for the quality aging wines. The cork oak forests are living representatives of sustainability and a driving force of sustainable development.
\end{abstract}

KEYWORDS: Mediterranean western, Quercus suber L., ecosystem services, cork properties.

\section{INTRODUCTION}

Cork or the phellem layer of the bark is a structure of additional protection of cork oaks (Quercus suber L.) and from viewpoint anatomical is a part of the periderm (Pereira 2007, Costa et al. 2020a). It can be first obtained after the 20-25 years growth of cork oak, which it is known 
as "bornizo" or "virgem" cork in Spain and Portugal, respectively. It is cracked and of low quality, so it is intended for crushing. Between nine and twelve years after the first uncorking, the "segundero" or "secundeiro" cork have a better quality, but still deficient. The cork sheets do not reach optimum quality until another 9-12 years uncorking period (3rd uncork) has happened, when the cork tree is approximately 60 years old. The best cork sheets are mostly used for the manufacture of stoppers (Paulo et al. 2015). Later, cork collection is done every 9-15 years, cork of reproduction, equivalent to the average time for the trees to produce a new bark layer around $30-40 \mathrm{~mm}$ thick (Costa et al. 2020a). Uncorking is a totally sustainable process that does not harm the tree (Faias et al. 2018, Branco et al. 2020).

Cork is composed of suberin, lignin, holocellulose, and extractives. Suberin is the principal component, $30-50 \%$ of cork's cell walls, and it is accumulated on the secondary walls. The lignin percentage has been found to range between 20 and $25 \%$, and the polysaccharide concentration is relatively small (Song et al. 2017). Due to cell wall structure, chemical composition and lignocellulosic materials, cork's performance is exceptional compared with other materials (Costa et al. 2020b). It is light, compressible and impermeable, and has many outstanding properties including of low thermal conductivity, energy-absorbing capacity, extraordinary friction resistance, and excellent sound insulation (Pereira 2007, Shiqian et al. 2018, Branco et al. 2020). Cork is one of the most appreciated natural products. The natural cork stopper is the closure chosen for the best quality aging wines (Gil 2014). Wineries pay a high price for them and require a guarantee tightness and absence of defects aroma, increasing demand for quality controls for the cork industry (Diaz-Maroto and Tahir 2016). The industry must have efficient analysis systems that allow it to select cork in the forest and monitor their evolution until obtaining the cork stoppers, following a strict traceability program, which will contribute broaden the knowledge about cork, wine, and their interaction (Alanon et al. 2013).

The cork oak is a Mediterranean species covering a global area of 2,139,942 hectares; Portugal and Spain are the countries where it occupies a larger area. The annual world wine production is around 275 million hectolitres (292 Mhl in 2018) (Statistical Report on World Vitiviniculture), and $90 \%$ of bottle wines are stopped by corks. In cork stoppers manufacture about 300 thousand tons of cork are utilised annually, and the cork waste is $25 \%$ of the raw material (Reis et al. 2019). The cork is used for a wide variety of products, including sealing materials and gaskets, heat and sound insulating materials, construction materials, and all type of ornament. Among the biobased materials that give satisfactory results in sound protection we can find black agglomerated cork with composite panels.

Sustainable Forest Management (SFM) seeks to make sure a behaviour of forest ecosystems environmental and socio-economically appropriate. This is difficult to achieve in the Mediterranean forests, because they have a partial capacity to respond to regular changes, human influences, large climatic, edaphic, and biological variety, and a complicated socioeconomic environment (Sánchez-González et al. 2005). Their management forestry presents a complex problem, being relevant in the cork oak forests since of their silvicultural features (Montero and Cañellas 2003). The cork is removed periodically without cutting down the trees. So, cork oak stands need to implement the SFM for finding solutions to their current problems (Torres and Montero 2000, Cañellas and Montero 2002): scarce natural regeneration, ageing of stands, quality loss, intense pruning, and cork oak decline, "seca".

Our aim was to analyse possible alternatives to carry out a system of payment for ecosystem services and/or a forest certification system in private small stands of Quercus suber, area less than 25 hectares. These forests are important ambassadors of environmental and socioeconomic sustainability and a driving force for sustainable development. They play a decisive role in the ecological balance, fighting climate change and desertification and maintaining biodiversity. 


\section{MATERIAL AND METHODS}

\section{Study framework}

Cork oak forests are distributed along the western Mediterranean basin, concentrating on the Iberian Peninsula, being the single species Quercus suber, evergreen tree belonging to the family Fagaceae. Cork oak forests cover a worldwide area of over 2,100,000 ha (Gil 2014). In Spain occupy more than half a million hectares and are set in the southwest (Extremadura and Andalucía) and west (Cataluña). The annual output is 340,000 tons, and it is the second largest world producer with $30 \%$, surpassed only by Portugal with $61 \%$. In both countries they are placed near 300 companies linked to the cork, highlighting the stopper industry, $85 \%$ of the turnover of the sector.

Cork oak woodlands in Spain and Portugal can be classified into open cork oak forests, 10 to $60 \%$ canopy cover and understory well-developed annual grasslands, called "dehesas" and "montados", respectively (Campos et al. 2020). And, cork oak forests, higher tree density and an understory of shrubs such as Arbutus unedo L., Juniperus spp., Ulex spp., Cistus spp., and aromatic species, according to environmental, silvicultural, and socioeconomic characteristics (Montero and Cañellas 2003, Pereira 2007). The main production in open cork oak forests is cork extraction, but they also provide grazing for domestic and wild livestock.

Moreover, the diversity of productions associated, such as: obtaining firewood, acorn production, maintaining and enhancing biodiversity, and landscape miscellany, grant the cork oak an advantaged position amongst forest species of the Iberian Peninsula (Montero and Cañellas 2003, Vogiatzakis et al. 2020). It is expected interspecific competition between trees and understory affects stand growth patterns, along with intraspecific competition and forest structure (Diaz-Maroto et al. 2005, Faias et al. 2018). The presence of understory may be positive for some soil process as it contributes to the nutrient concentration and may improve natural regeneration development (Diaz-Maroto et al. 2010).

\section{Payment for ecosystem services versus forest management certification: Growth models}

On the one hand, the conservation of cork oak woodlands and implementation of the SFM actions may be addressed by means of payment for ecosystem services and/or certification of forest management, following to the traceability program of raw materials, through processing to obtain the final products, i.e. from the forest to the consumers; such as the Forest Stewardship Council (FSC) and PEFC (Pollastrini et al. 2017, Reis et al. 2019). FSC certification for cork oak forest management is now implemented in Portugal, Spain, and Italy; PEFC certification currently applies in cork oak forests in Portugal and Spain (Tab. 1) (Pollastrini et al. 2017).

Tab. 1: Certified cork oak surface area (ha) in some countries by Forest Certification System.

\begin{tabular}{|l|c|c|c|}
\hline $\begin{array}{l}\text { Country/Forest Certification } \\
\text { System }\end{array}$ & Portugal & Spain & Italy \\
\hline FSC (2017) & 357,386 & 159,695 & 66 \\
\hline PEFC (2017) & 109,058 & 21,000 & $(1)$ \\
\hline
\end{tabular}

(1) Only three public forests (over 8,000 ha, including cork oak woodlands) managed by the Regional Forest Agency for Land and Environment of Sardinia were FSC-certified for firewood forest management.

On the other hand, growth models can add to the forest management decision making so long as provide stand development forecasts. The growth models for dominant trees are very 
suitable in the management of open cork oak forests. For a given site index, the height growth curves allow us to estimate the minimum time that a natural regeneration plot must be closed off to livestock. This period has a great economic and silvicultural significance (Sánchez-González et al. 2005). If this period is not long enough, there is a risk that wildlife or domestic fauna will seriously damage the young trees. Those damaged trees, if they survive, will have short and/or crooked stems, which will affect to the production of quality cork. The period of protection must last until the young trees reach of $2 \mathrm{~m}$ (Sánchez-González et al. 2005, Diaz-Maroto and VilaLameiro 2007).

The number of years required for a cork oak to reach a height of $2 \mathrm{~m}$ can be estimated to 10 and 30 years for the best and worst qualities, respectively (Sánchez-González et al. 2005).

\section{Status of the cork sector: Scheme of Regional Model of Forest Certification}

In Spain, according to data available until 2017, it had been certified more than 180,000 hectares of cork oak (Tab. 1), and about 30 companies in the sector had obtained the certification of the chain of custody, through the FSC and PEFC systems. This process must be leaded by the Regional Groups of Forest Certification and Chain of Custody (Fig. 1). As specified by the multifunctional forestry applied in the Quercus suber forests, its main use is the production of cork stoppers for the quality aging wines.

\section{Regional Model of Forest Certification}

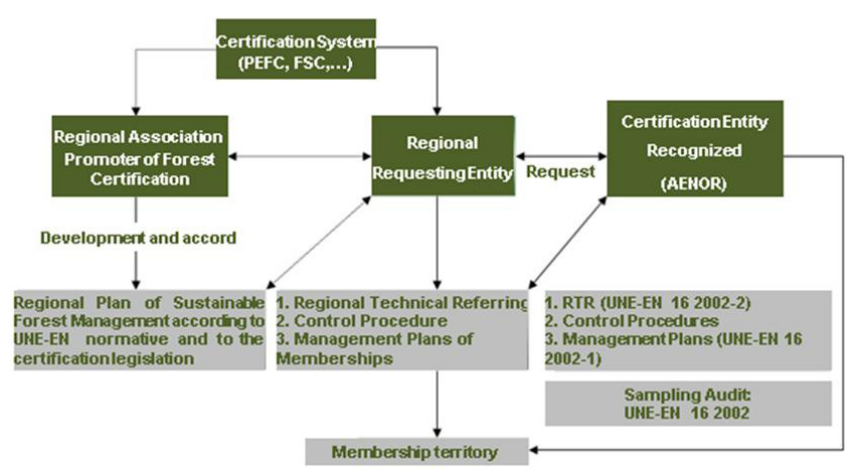

Fig. 1: General scheme of Regional Model of Forest Certification.

\section{RESULTS AND DISCUSSION}

\section{Forest Certification process in small open cork oak stands}

Local governments and public institutions have understood sustainability in procurement of both timber and non-timber products is a key responsibility and an important element in forwardlooking policies and activities (Baharuddin and Simula 1994). It is an integral part of the role of the public sector to contribute to the aspirations of the community and to meet their needs within the limits of our planet. Aware of the significance of promoting SFM, national and local governments have made sustainable procurement of wood and non-wood products, such as cork, is a key requirement for public purchasing (ProForest 2006). Many have put in place legislation to this effect to tackle illegal logging and help prevent illegally harvested wood or the timber from unsustainable sources getting in the market. 
Certification may provide an added value to the final products, while safeguarding commercial rights of local communities and increasing economic benefits. However, limited knowledge on sustainable cork oak management practices hinders the application of good practices and SFM indicators (Robak et al. 2012). Certification systems have been accepted in all public procurement policies worldwide given their evidence, both sustainability and legality, and all systems include as minimum the following requirements (Baharuddin and Simula 1994, Badalamenti et al. 2020): i) safeguard ecologically important forest areas; ii) protect and enhance biodiversity; iii) prohibit hazardous product chemicals; iv) prohibit genetically modified trees; v) respect the rights of workers and indigenous people; vi) encourage local employment; vii) comply with International Labour Organization (ILO) principles; viii) respect traditional land rights and local customs.

Fig. 2 about the Galician Model of Forest Certification illustrates as the Regional Requesting Entity (PEFC-Galicia) needs a management plan for the forests.

\section{Galician Model of Forest Certification}

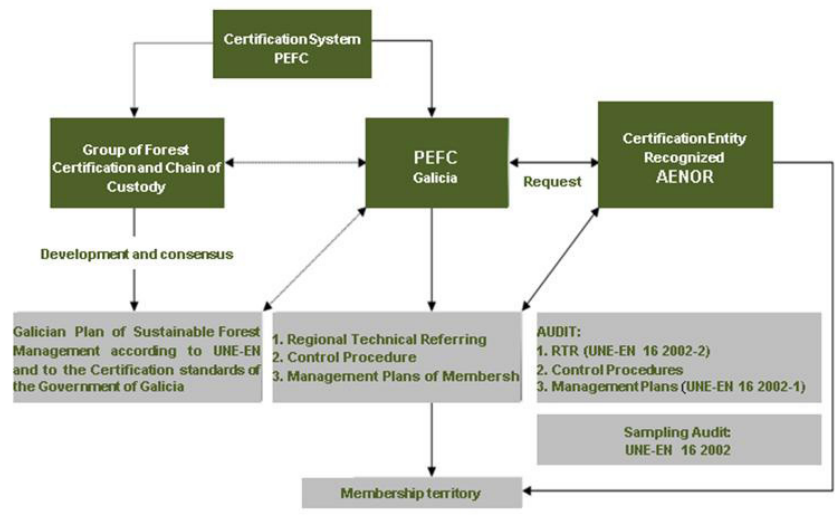

Fig. 2: Galicia Model of Forest Certification process.

However, as the Regional Groups of Forest Certification and Chain of Custody have designed a specific certification process, these plans are considered by great areas (Robak et al. 2012).

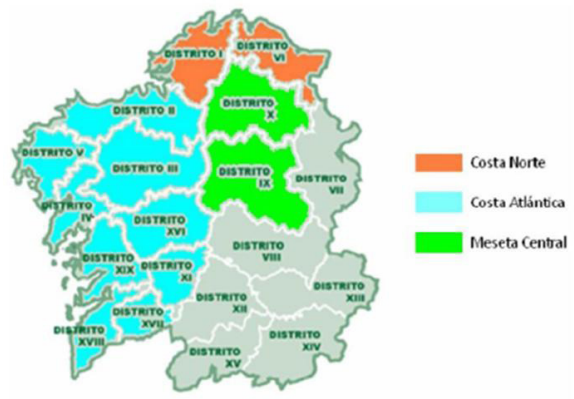

Fig. 3: Application ambit of management plans of Forest Certification. 
So, in the Fig. 3 is showed the limits of the management plans of the SFM System apply for the Group of Forest Certification and Chain of Custody in Galicia. As it can be seen, the territory is divided in four areas: North coast, Atlantic coast, Central plateau, and the rest. Each area is denoted by a division of Forestry Management in Galicia, the "District".

\section{Certification process timeline}

Following be show the process to implement a forest certification system in small stands of cork oak of an area $<25$ ha (Tab. 2).

Tab. 2: Forest Certification System: private small stands of Quercus suber L.

\begin{tabular}{|l|l|l|l|}
\hline Certification process & Number of stands & \multicolumn{1}{|c|}{ Notification } & \multicolumn{1}{c|}{ Observations } \\
\hline Process start & $\begin{array}{l}\text { It can be done } \\
\text { simultaneously for } \\
\text { several stands. }\end{array}$ & $\begin{array}{l}\text { The notification must be } \\
\text { included the plot reference } \\
\text { code and the start date of } \\
\text { authorization for uncorking. }\end{array}$ & $\begin{array}{l}\text { The exploitation date } \\
\text { beginning may be } \\
\text { informed to the }{ }^{1} \mathrm{RG} \\
\text { prior to process start. }\end{array}$ \\
\hline $\begin{array}{l}\text { Conclusion of } \\
\text { the request for } \\
\text { exploitation-Removal } \\
\text { of certified cork sheets }\end{array}$ & $\begin{array}{l}\text { It can be done } \\
\text { simultaneously for } \\
\text { several stands. }\end{array}$ & $\begin{array}{l}\text { It must be included the } \\
\text { reference code and the ending } \\
\text { date by plot. If retreat note of } \\
\text { certified cork is required shall } \\
\text { be requested to the } 1,2 \mathrm{RG} .\end{array}$ & $\begin{array}{l}\text { The ending date of } \\
\text { harvesting may be } \\
\text { communicated to }{ }^{1} \mathrm{RG} .\end{array}$ \\
\hline $\begin{array}{l}\text { Forest Certification } \\
\text { process taxes }\end{array}$ & $\begin{array}{l}\text { Individually in each } \\
\text { stand. }\end{array}$ & $\begin{array}{l}\text { 3The current taxes are } \\
\text { between } 0.25 \text { and 2.00 €/Tm. Tm. }\end{array}$ & $\begin{array}{l}\text { The certification process } \\
\text { has a cost of transaction. }\end{array}$ \\
\hline $\begin{array}{l}\text { Current situation of } \\
\text { Forest Certification } \\
\text { in the private oak cork } \\
\text { forests }\end{array}$ & $\begin{array}{l}\text { Individually in each } \\
\text { stand. }\end{array}$ & $\begin{array}{l}\text { The certified cork versus not } \\
\text { certified imply a price increase } \\
\text { around } 15 \text { or } 20 \%\end{array}$ & $\begin{array}{l}\text { The transaction cost } \\
\text { cannot mix to the cost of } \\
\text { the certification process. }\end{array}$ \\
\hline
\end{tabular}

${ }^{1}$ RG: Regional Groups; ${ }^{2}$ The request must indicate the quantification method of the cork, by volume or by weight; ${ }^{3} 0.25 € / \mathrm{Tm}$ : if the company that performs uncorking on plot of membership is also a member of FEARMAGA or Monte Industry (Forest manufacturing associations in Galicia), and $2.00 € / \mathrm{Tm}$ in the rest.

Galician private forests were under increasing pressure to show the implementation of SFM and due diligence regarding the purchase of wood from sustainable sources. The growing importance of certification in the forest product marketplace and legislative initiatives such as European Regulation (EU) No 995/2010 or Spanish Order Pre/116/2008, have been effective in increasing pressure on the private sector. Also, the global economic recession that followed the collapse of major US financial institutions notably reduced demand for forest products. SFM, considered by many actors as an instrument for reaching new marketplaces, suddenly, it became an obligatory tool to keep the decreasing supply, with increasing demand, wood mainly, that was taking place (Robak et al. 2012). Because of these increasing pressures, and other important factors such as the current growing demand from consumers, forest certification systems have been applied successfully in the forestry sector and the Galician forestry sector, particularly.

\section{Payment for ecosystem services: SFM indicators for Quercus suber forests}

A group of SFM indicators was chosen for Quercus suber forests based in the data on the structure of the stands, origin, phytosanitary status, dendrometry characteristics and management methods, obtained from different forest management plans in these forests or in forests of species of the genus Quercus in the study area. The indicators were conceived as "forest 
management indicators" and were chosen by bibliographic review (Cañellas and Montero 2002, Montero and Cañellas 2003, Diaz-Maroto et al. 2005, 2010, Sánchez-González et al. 2005, Robak et al. 2012, Paulo et al. 2015, Pollastrini et al. 2017, Faias et al. 2018). The indicators were established considering possible problems of management and the ecological characteristics of the cork oak forests (Badalamenti et al. 2020). In addition, the viability of obtaining indicators on management planning was also assessed.

The requirement to improve the environment of cork oak forests stands out, as well as growing economic income through the certification of the SFM. Significant limiting factors for uncorking were the health and vitality of the cork oaks and the protective function of the forest, given the multifunctional nature of these ecosystems.

\section{CONCLUSIONS}

(1) At the beginning, Sustainable Forest Management developed quickly. However, the implementation of its strategic framework has been delayed. Greater effort obtaining clarity of roles and support from all stakeholders at the SFM, could have led to more progress. Meanwhile, the forestry industry suffered increasing pressure from the markets and public opinion to demonstrate that it had adopted sustainable practices. (2) The private forest sector, which is moving in this way despite the difficulties caused by the small exploitations and fragmented ownership, has begun the SFM implementation leaded by means of payment for ecosystem services and/or certification of forest management and chain of custody; which could reduce some of forest sector problems. (3) Some positive outcomes associated with administration's strategy have been achieved by private initiatives in a short period of time, there are reasons to be optimistic. Finally, to comment the general perception on current conditions of the cork oak forests in the sense of improving the current silvicultural treatments to reach sustainable management.

\section{ACKNOWLEDGEMENTS}

This research was carried out under the support of a Grant financed by the Spanish Ministry of Science, Innovation and Universities. Its purpose is to finance mobility stays for Professors and Researchers in Foreign Centres of Higher Education and Research. So, we have a debt of gratitude to the Secretary of State for Universities, Research, Development and Innovation, Mobility Subprogram of the State Program for the Promotion of Talent, and its Employability, State Plan of R+D+i 2017-2020. Authors thanks to the Junta de Comunidades de Castilla-La Mancha, Spain, for the Research Project SBPLY-17-180501-000445.

\section{REFERENCES}

1. Alanon, M.E., Schumacher, R., Castro-Vazquez, L., Diaz-Maroto, I.J., Diaz-Maroto, M.C., Perez-Coello, M.S., 2013: Enological potential of chestnut wood for aging Tempranillo wines part I: Volatile compounds and sensorial properties. Food Research International 51: 325-334.

2. Badalamenti, E., Scalenghe, R., La Mantia, T., Da Silveira, R., Sala, G., Pizzurro, G.M., Giaimo, A., Pasta, S., 2020: The cork oak in the Mountains of Palermo (Italy): ecological insights from the south-eastern edge of its distribution range. Iforest-Biogeosciences and Forestry 13: 366-344. 
3. Baharuddin, Hj.G., Simula, M., 1994: Certification schemes for all timber and timber products. ITTO, Yokohama, Japan, 54 pp.

4. Branco, D.G., Campos, J.R., Cabrita, L., Evtuguin, D.V., 2020: Structural features of macromolecular components of cork from Quercus suber L. Holzforschung 6: 625-633.

5. Cañellas, I., Montero, G., 2002: The influence of cork oak pruning on the yield and growth of cork. Annals of Forest Science 59: 753-760.

6. Campos, P., Alvarez, A., Oviedo, J.L., Mesa, B., Caparros, A., Ovando, P., 2020: Environmental incomes: Refined standard and extended accounts applied to cork oak open woodlands in Andalusia, Spain. Ecological Indicators 117: 106551.

7. Costa, A., Barbosa, I., Pestana, M., Miguel, C., 2020a: Modelling bark thickness variation in stems of cork oak in south-western Portugal. European Journal of Forest Research 139: 611-625.

8. Costa, R., Lourenco, A., Oliveira, V., Pereira, H., 2020b: Chemical characterization of cork, phloem, and wood from different Quercus suber provenances and trees. Heliyon 10(6): e03468.

9. Diaz-Maroto, I.J., Vila-Lameiro, P., Silva-Pando, F.J., 2005: Autecology of oaks (Quercus robur L.) in Galicia (Spain). Annals of Forest Science 62: 737-749.

10. Diaz-Maroto, I.J., Vila-Lameiro, P., 2007: Deciduous and semi-deciduous oak forests (Quercus robur, Q. petraea and Q. pyrenaica) floristic composition in the Northwest Iberian Peninsula. Biologia 62: 163-172.

11. Diaz-Maroto, I.J., Fernández-Parajes, J., Vila-Lameiro, P., Barcala-Pérez, E., 2010: Site index model for natural stands of rebollo oak (Quercus pyrenaica Willd.) in Galicia, NW Iberian Peninsula. Ciência Florestal 20: 57-68.

12. Diaz-Maroto, I.J., Tahir, S., 2016: Analysis of physical properties of wood in three species of Galician oaks for the manufacture of wine barrels. Part I: Wood infradensity. Wood Research 61: 683-696.

13. Faias, S.P., Paulo, J.A., Palma, J.H.N, Tomé, M., 2018: Understory effect on tree and cork growth in cork oak woodlands. Forest Systems 27: 11967.

14. Gil, L., 2014: Cork: A strategic material. Frontiers in Chemistry 2: 1-2.

15. Montero, G., Cañellas I., 2003. Selvicultura de los alcornocales en España (Forestry of the cork oaks in Spain). Silva Lusitana 11: 1-19.

16. Paulo, J.A., Palma, J.H.N., Gomes, A.A., Faias, S.P., Tomé, J., Tomé, M., 2015: Predicting site index from climate and soil variables for cork oak (Quercus suber L.) stands in Portugal. New Forests 46: 293-307.

17. Pereira, H., 2007: Cork: Biology, production and uses. Elsevier Sci., Amsterdam, The Netherlands, $346 \mathrm{pp}$.

18. Pollastrini, M., Chiavetta, U., Cutini, A., Casula, A., Maltoni, S., Dettori, S., Corona, P., 2017: Indicators for the assessment and certification of cork oak management sustainability in Italy. iForest 11: 668-674.

19. ProForest 2006: Evaluation of the Danish guidelines on public purchase of tropical timber, Sub Project B. Danish Forest and Nature Agency, Copenhagen, Denmark.

20. Reis, S.F., Lopes, P., Roseira, I., Cabral, M., Mateus, N., Freitas, V., 2019: Recovery of added value compounds from cork industry by-products. Industrial Crops and Products 140: 111599.

21. Robak, E., Aboal, J., Picos, J., 2012: Sustainable forest management in Galicia (Spain). In: Julio J. Diez (Ed.): Lessons learned, Sustainable forest management - Case studies: 221-238, IntechOpen Limited, London, UK, 270 pp. 
22. Sánchez-González, M., Tomé, M., Montero, G., 2005: Modelling height and diameter growth of dominant cork oak trees in Spain. Annals of Forest Science 62: 633-643.

23. Shiqian, W., Song, X., Yafang, L., Mingqiang, Z., 2018: Characterizations and properties of torrefied Quercus variabilis cork. Wood Research 63: 947-958.

24. Song, X., Lingyan, Z., Shiqian, W., Yafang, L., 2017: Structural and mechanical properties of cork cell walls from Quercus variabilis Blume (Fagaceae). Wood Research 62: 873-882.

25. Torres, E., Montero, G., 2000: Los alcornocales del Macizo del Aljibe y Sierras del Campo de Gibraltar (Cork oak forests of the Massif of El Aljibe and Mountains of the Campo de Gibraltar). MAPA, Madrid, Spain.

26. Vogiatzakis, I.N., Griffiths, G.H., Zomeni, M., 2020: Incorporating landscape character in cork oak forest expansion in Sardinia: constraint or opportunity? Forests 11: 593.

Ignacio J. Diaz-Maroto

Escuela Politécnica Superior De Ingeniería

Universidad De Santiago De Compostela

E-27002 Lugo

España

*Corresponding author: ignacio.diazmaroto@usc.es

\author{
María Consuelo Diaz-Maroto \\ Food Science and Technology \\ Regional Institute for Applied Scientific Research \\ Universidad De Castilla-La Mancha \\ E-I307i Ciudad Real \\ España
}


